\title{
Over-commitment to the job and the organisation: implications of excessive job involvement and organisational attachment
}

\author{
Michael P. O'Driscoll*
}

Research and managerial practice have both put emphasis on the development of high levels of job involvement and organisational attachment, stemming from the assumption that employee commitment benefits the organisation and the individual. However, there are indications that over-commitment may have negative consequences for employees and employers. This paper discusses potentially detrimental outcomes of excessive commitment to the job and the organisation and examines the implications of overcommitment for individuals, organisations and values within society. Future research and human resource management should be based upon a more balanced view of the interaction between job demands and the person's off-the-job interests, commitments and responsibilities.

\section{Introduction}

Commitment to work has occupied a central position in theoretical and applied perspectives on work attitudes and behaviour. While distinctions have been made between various forms of commitment, including commitment to a job or career, commitment to the employing organisation, commitment to a profession, and commitment to a union, many of which may overlap with each other (Angle \& Perry, 1981; Morrow, 1983), substantial interest has been shown in two major areas: involvement in the job and attachment to the employing organisation. A pervasive theme is that, to be effective, organisations need employees who are highly involved in their work, who identify with the goals and values of their employer and who are attached and loyal to their company, firm or agency. In keeping with this view, numerous studies have been conducted to establish positive relations between high levels of commitment and job performance, reduced absenteeism and turnover, and organisational effectiveness.

With a few exceptions (see Randall, 1988), considerably less attention has been given to the negative implications of high levels of involvement in one's job or attachment to the employing organisation. The present paper examines potential linkages between high commitment to the job and the organisation and undesirable outcomes for both employees and employers, and reviews the implications of these relationships for personnel management.

Two central concepts in this review are job involvement and organisational 
attachment. Following Rabinowitz and Hall (1977) and Kanungo (1979), job involvement is defined as the psychological importance of the job to the individual or the extent to which the job is a central life interest (Dubin, 1956). Involvement in this context refers to the relative salience of the job compared with other areas of life (such as family, recreational pursuits, political activities, community roles). While many different the describe job involvement, there is general consensus that relevance to the person's self-image is a fundamental characteristic of this construct (Rabinowitz \& Hall, 1977).

Organisational attachment refers to an individual's degree of identification with the goals and values of an organisation and desire to remain a member of it (Mowday, Steers and Porter, 1979). At the core of this definition is the psychological bond which is developed with the company or firm (O'Reilly \& Chatman, 1986). This form of commitment contains several dimensions which are closely interrelated (Angle \& Perry, 1981; Mowday, Porter \& Steers, 1982).

An alternative approach to these psychological and managerial perspectives comes from organisational sociologists such as Etzioni, who has distinguished between an expressive orientation to work, in which the individual seeks and obtains fulfillment from the job, and an instrumental attitude based on the material gains or rewards resulting from showing commitment to the job or organisation (Etzioni \& Gross, 1985). In a similar vein, O'Reilly and Chatman (1986) discuss the difference between moral attachment to an organisation, founded on value congruence between the person and the organisation, and calculative involvement, where the individual exhibits compliance for specific extrinsic rewards (such as job security and higher pay). This approach explicitly acknowledges individual differences in the degree to which the job occupies a central niche in people's lives and makes no assumptions about the relative merits of different work orientations. Expressive and instrumental attitudes toward work are viewed as having both positive and negative implications.

\section{Potential outcomes of high commitment}

Empirical research has focused predominantly on the benefits of high levels of job involvement and organisational attachment. Humanistic theories of work motivation (frequently based on Maslow's need hierarchy model and Herzberg's two-factor theory of motivation/satisfaction) propose that, in addition to material rewards, job involvement motivation/satisfaction) propose that, in addition to material rewards, job involvement
provides psychological fulfillment. Involvement is viewed, therefore, not only as desirable but as a prerequisite for personal growth.

Although links with job performance are tenuous (Morrow, 1983), job involvement has been related to reduced turnover intentions and absenteeism (Cheloha \& Farr, 1980; Rabinowitz \& Hall, 1977). Overall, it would appear to be in an organisation's best interests to promote and sustain individual involvement in the job. Organisational attachment has also been assumed to have both individual and organisational consequences. For the employee, identification with an organisation can provide a sense of identity and belonging, purpose and direction, along with job security, promotio opportunities, increased responsibility and autonomy on the job, and social approval from colleagues and superiors (Mowday, Porter \& Steers, 1982). Like job involvement, greater attachment has been correlated with reduced turnover (Bateman \& Strasser, 1984; Blau \& Boal, 1987; DeCotiis \& Summers, 1987) and, to a lesser extent, lower absenteeism (Little, 1985) and tardiness (Angle \& Perry, 1981). In one of the few comparisons of the relative influence of different types of work commitment, Blau \& Boal (1987) argued tha involvement and attachment complement each other as predictors of absenteeism and turnover, but that in general involvement accounts for more variance in absenteeism, while identification with the organisation is responsible for more variance in turnover DeCotiis and Summers (1987) observed a positive correlation between attachment and objective measures of individual job performance, but significant links with total organisation effectiveness have not been demonstrated (Angle \& Perry, 1981)

Overall, it is evident that extant research has concentrated on the desirability of high commitment, and reflects the human relations perspective on employee-organisation and person-job linkages. However, a balanced critique also requires consideration of possible deleterious consequences of excessive involvement in one's job or attachment to a particular organisation.

\section{Negative consequences for the organisation}

Using the Nazi concentration camps during World War II as an illustration of excessive commitment, Salancik (1977) noted that too much loyalty to an organisation can be disadvantageous to organisational flexibility and can lead to a "reaffirmation of past mistakes" and resistance to change. Escalation of investment may lead to entrapment process by which investments go beyond the limits which are justified by the value of the goal being pursued.

Uncritical acceptance of organisational values, goals and procedures may be anothe consequence of extreme identification with a particular organisation. The phenomenon of "groupthink", identified by Irving Janis (1972) in his observations of decision making processes in US government congressional committees during the $1960^{\prime} \mathrm{s}$, may emerge in situations where there is an over-emphasis on conformity, on maintaining a facade of unanimity and consensus despite real differences in values and atitudes facade of commitment in organisational members may exacerbate groupthink (Morrow, 1983), resulting in organisational stagnation.

Angle and Perry (1981) have noted that extreme organisational attachment may lead to "fanatical behaviour" and the suspension of individual judgment, exemplified vividly by the ritualistic mass suicide and murder of 900 people in Jonestown, Guyana in November, 1978. The insistence by Rev. Jim Jones on total commitment from his followers represents an extreme case of over-socialization into the norms of obedience conformity, as was the behaviour of soldiers in the Nazi concentration camps and in the My Lai massacre in Vietnam. Nevertheless, Miloram's cerpering illustrate that, given a conducive environment, these same processes may be observed in the behaviour of many people in any society (Milgram, 1974).

The relevance of these issues for work organisations has been highlighted by Randall (1987), who has presented the most comprehensive discussion to date of the pondal langers of excessive levels of organisational identification. negative consequences: (1) lack of creativity and innovation within the organisation; (2) resistance to change; (3) overzealous conformity to organisational policies and procedures; (4) a willingness to engage in corporate crime (winess, for policies and procedures; high level fficis ines, for example, the behaviour of 1970's): officials in the Watergate scandal of the Nixon administration during the early 1970's); and (5) mismanagement of human resources, coupled with an inability to remove ineffective and unproductive personnel. Over-emphasis on compatibility with existing organisational beliefs and attitudes during personnel recruitment and impede creativity and progress within the company or agency. Many of these consequences apply equally well to extreme levels of job involvement.

\section{Negative consequences for the individual}

The hazards of extreme commitment for individuals have been reflected in concern about stress and conflict in family relationships (Margerison \& Kakabadse, 1984) and tension in other social relations outside of the work environment (Mowday et al., 1982), while links between over-involvement in the job and the physical and psychological 
consequences of Type A behaviour, characterized by extreme aggressiveness, constessness and anxiety, competitivess and amon (Ward \& Eisler, 1987)

(1985) identified demands from work and family roles as majo ( They view job involvement as a critical moderator of sources of interrole conflict. They" vide conflict between work and "nonwork" domains. It is evident that individuals who devote extra time to the job and sacrifice personal interests and responsibilities for priorities may experience severe disruption in their off-the-job lives (Jackson, Zedeck \& Summers, 1985; Randall, 1987).

Very high levels of work commitment may also contribute to job stress and burnout, which heen defined as "a three-component syndrome involving emotional exhaustion, which has been defined as "a throm depersonalization and feelings of low persing Schuler, 1986, p. 637). There is growing evidence that burnout has become iniss, 1980) pervasive among personnel employed in human service organisations (Cheniss, 1980), especially those having direct contact with and care of other people (Jackson, 1984). Relationships between burnout and job satisfaction, productivity, absenteeism and Reen strated in numerous studies (see O'Driscoll \& Schubert, 1988).

Hall and Rich overlap betwen the work

Hall and Rich inability to dissociate oneself from and home life can cause employee burnout, due to al ine and Clarke (1985) suggested problems occurring in the work environment, while In that job involvement may distract individuals from their spouses and famies, hence reducing the social support available to them in times of stress, and even create stress through disruptions to family life. Finally, excessive commitment may lead to less flexibility when confronted by the need to adapt to changed circumstances. Too much flexibility when cobility, reducing opportunitie attachment to an organisation can il al, 1982; Randall, for car 1987).

Implications for organisations and personnel management

Many techniques utilised to increase employee motivation and job performance and Many technique utilised to in employee heighten organisational productivity are built upon a pherm benefits involvement and commitment. As noted above, while the may be sher term benefrs for the organisation in promoting higher commitment, frequently the longer tem hazard of this approach have been overlooked or downplayed. To illustrate the implications of ork commitment for organisational practices and policies, four major issues will be work commitment for mativision, job redesign, participation in decision making discussed: employee motivation,

As noted earlier, most current perspectives on work motivation adopt a humanistic As noted earlier, most current perspectives on work motivation adopt a humatiction motives (such view of individual behaviour, which assumes that satisfaction of "intrinsic "motives (such as autonomy, control and achievement) is a more effective strategy for increasing motivation (and hence job performance) than simply providing "extrinsic" incentives, such as material rewards and job security. Kanungo and Misra (1988) suggest, however, that "different sets of needs may be salient in different life contexts" (p. 269). In addition, "different sets of nee satisfy intrinsic needs in the there are few

ork setting. Limitations of the emphasis on intrinsic motivation are Snyderman (1959), Turner
redesign. Since the pioneering work of Herzberg, Mausner and Snyes and Lawrence (1965) and, in the 1970's, Hackman and Oldham (1976), changes in the design of jobs have been frequently introduced by organisations in their attempts to increase levels of individual job performance and improve the quality of work life. increase levels of individual job pertermics model, which is the foundation of most Hackman and Oldham's job charal be equated with higher job involvement) will respond more favourably to changes that offer them greater variety in their work, more autonomy and greater skill utilization. To date, however, research has not uniformly demonstrated any systematic advantage of high involvement for work design interventions. Consistent with arguments presented above about the relative potency of various motives for different individuals, the assumption that promoting high levels of work commitment in individuals is necessary for ensuring the effectiveness of job enrichment and other types of work redesign may be empirically unfounded.

Participation in decision making is the organisational change strategy which relies most heavily on employee involvement. It has been advocated as an effective mechanism for increasing the control which employees have in their work environment, distributing power and authority more evenly throughout an organisation, and ultimately enhancing both individual and organisational performance. Numerous studies have been conducted to identify gains resulting from the introduction of this form of management and one commentator (Sashkin, 1986) has gone so far as to assert that participation is an "ethical commentator (Sashkin, 1986) has gone so far as to assert that participation is an "ethical
imperative", since it prevents the occurrence of mental health problems which can accrue imperative", since it prevents the occurrence of mental health problems which can accrue
from work that underutilizes people's skills, lacks variety and challenge, and gives them little or no control.

Nevertheless, research focussing on the consequences of participative management systems has obtained equivocal findings on the impact of this approach. Cotton, Vollrath, Froggatt, Lengnick-Hall and Jennings (1988) have concluded that employee involvement in work decisions can have positive benefits for performance and productivity, but that the effects on job attitudes are inconsistent. They note that Quality Circles, one of the major forms of participation, do not always augment employee work satisfaction. Locke, Schweiger and Latham (1986) have argued that there is no clear tendency for participative decision making to lead to higher productivity than autocratic management and that participation is simply a managerial technique which is appropriate in some circumstances and not others. They refer also to research on goal-setting, which has shown no systematic effect of participative versus assigned goals.

As with many approaches to employee motivation and work redesign, the rationale for participative decision making rests on theories of human growth and development which assume that individuals want to be psychologically involved in and have some control over organisational processes which have a bearing on their job. In these formulations, participation constitutes a major link in the chain of needs or values which individuals seek to fulfill. Like other needs and values, such as security, affiliation and achievement, fulfillment of the need to be involved and the need for control is anticipated to enhance levels of job satisfaction. Locke and his colleagues (1986) have pointed out, however, that a job consists of multiple components which may contribute toward satisfaction including pay, promotion, the physical work environment, job security, and so on. Participation may be just one of many job-related values.

One individual difference variable which is highly salient to participation in decision making is the employee's expectations. Abdel-Halim (1983) noted that participation is a form of power equalization within an organisation, but that not everybody operates effectively within a participative framework. The motivation to participate or exercise power, along with the consequences of this kind of involvement, determine the effectiveness of this strategy.

The premise that employees value participation in management processes and involvement in their jobs has rarely been challenged. Over the past two decades, there have been numerous attempts to improve quality of work life and productivity by introducing one or other form of participative management, but research findings on the outcomes of these interventions have shown no consistent trend. There has been little questioning of the basic assumption on which these schemes are founded. Rather than maintaining unverified assumptions about employee needs and preferences, organisation should strive for a greater awareness of the values which individuals bring into their jobs 
and their expectations about what they will achieve in the work context (Ogilvie, 1986). Increased involvement via participation in managerial decision making may, in fact, be of lower priority than other work-related values.

Finally, as noted earlier more attention must be given to possible conflict between Finally job demands and life off the job. Forific demarcation of work/nonwork time. Greate responsibility, there may be no specific demarcation of work/nonwol over their work flexibility in working hours certainly offers employees greater control over their worses hours and may enable them to cater for off-the-job contingencies (such as family crises, child-care and even routine home management duties), but that same lack of specification child-care and boundaries between these two domains. Among individual can result in a blurring of bounisational attachment, working hours may be extended, a with high involvement and organisational attachmositites and interests. Under these circumstances, the expense of off-the-job responsibilities and costs which may contribute to burnout, as increased flexibility carries with it unrecogniz

consequence of over-exertion on the job.

Over a decade ago, Kanter (1977) observed that organisations can no longer sustain the myth of separation between job and off-job spheres of life. More recently, Hall and Richter (1988) have advocated that organisations should do more to foster effective (1) child rearing, home management and other nonwork management domains. Another involvement in the job, identification commitment may Immediate motivational and performance gains which result from high commitment mayday, Porter and be offset by less obvious costs to both employers and employees. Mowday, Porter and Steers (1982) have asked whether the development of high commitment in all employees is needed by an organisation and under what conditions greater commitment will be beneficial.

\section{Societal implications}

implications for individual well-being and

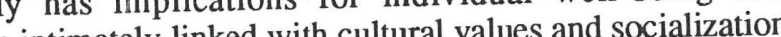
organisational effectiveness, but is intimately linked with cultural values and socialization practices. Lawler (1988) has commented that western societies are based on dhe "high principles which not only allow for, but actively encourage, the development of the "high involvement approach" to management. These principles generate no Deviation from these and involvement which are positively sanctioned by cultural values. Deviation fal fostered norms will be viewed as counter-productive and contrary to the democratic ideal fostered within society.

In contrast, the Marxist hypothesis of a dialectic tension between elements within In contrast, the exploitation of the workforce by employers. From thi society focus we is viewed not as a means of powe perspective, devolving greater control an redistribution and equalization, nor as a tech increasing organisational control over its responsibility to employees, but as a stragy for increals. The extent to members by ensuring their ideological commitment to its nor which organisations should exert control over individuals lives, both on and off the job requires greater attention from social scientists, human resource managers an requires grants an the organisational ches only place pressure on employees to techniques of modern persin in their jobs, but also encroach upon people's lives outside of show greater involvement in their jobs, but also encrications which extend beyond the their job. Organisational practices, he asserts, have ramifications which extend beyond the office door or the factory gates.

New Zealanders may not be subject to the same organisational demands and pressures semployees in countries such as Japan, where high commitment is a prerequisite for as empan mership and job security, but many individuals in this country occupy jobs activities include taking work home, attending weekend meetings and entertaining clients, to mention a few. Hall and Richter (1988) have commented that many organisations do not make any allowance for employees' private lives and for the transition between work and "nonwork" domains. Legislation regarding work hours and physical working and "nonwork" domains. Legislation regarding work hours and physical working conditions will not resolve the more pervasive influence that organisations can exert upon
their employees under the guise of industrial democracy, participative management or their employees under
quality of work life.

Similarly, because both private and public sector organisations are generally task- and productivity-oriented, to what extent does the emphasis on involvement and attachment promote greater work orientation in society, perhaps at the expense of other values? Unemployment research illustrating the critical importance for most people of having a job, along with recent increases in dual-career couples and flexible work schedules which job, along with recent increases in dual-career couples and flexible work schedules which
produce an overlap between job and off-job time, all suggest that the work ethic in society may be growing stronger, rather than diminishing. To date, however, little effort has been expended on assessing the societal implications of these trends. It is clear that a more critical appraisal of the nature of the employee-organisation relationship and the role of organisations within society is essential to provide an integration of managerial, psychological and sociological perspectives on the benefits and limitations of high commitment to the job and to the organisation.

\section{References}

Abdel-Halim, A (1983) Power equalization, participative decision-making and individual differences Human relations 36:683-704.

Angle, $\mathrm{H}$ and Perry, $\mathrm{J}$ (1981) An empirical assessment of organisational commitment and organisational effectiveness Administrative science quarterly 26:1-14.

Bateman, T and Strasser, S (1984) A longitudinal analysis of the antecedents of organisational commitment Academy of management journal 27:95-112.

Blau, G and Boal, K (1987) Conceptualizing how job involvement and organisational commitment affect turnover and absenteeism Academy of management review 12:288300

Cheloha, R and Farr, J (1980) Absenteeism, job involvement and job satisfaction in an organisational setting Journal of applied psychology 65:467-473.

Cherniss, C (1980) Staff burnout: job stress in the human services Beverly Hills, CA, Sage Publications.

Cotton, J, Vollrath, D, Froggatt, K, Lengnick-Hall, M and Jennings, K (1988) Employee participation: diverse forms and different outcomes Academy of management review 13:8-22.

DeCotiis, T and Summers, T (1987). A path analysis of a model of the antecedents and consequences of organisational commitment Human relations 40:445-470.

Dubin, R (1956) Industrial workers' worlds: a study of "central life interests" of industrial workers Social Problems 3:131-142.

Etzioni, A and Gross, E (1985) Organizations in society Englewood Cliffs, NJ, PrenticeHall. 
Fox, A (1985) Man mismanagement (Second edition) London, Hutchinson.

Greenhaus, J and Beutell, N (1985). Sources of conflict between work and family roles Academy of management review 10:76-88.

Hackman, J and Oldham, G (1976) Motivation through the design of work: test of a theory Organizational behavior and human performance 16:250-279.

Hall, D and Richter, J (1988) Balancing work and home life: What can organisations do to help? Academy of management executive 2:213-224.

Herzberg, F, Muasner, B and Snyderman, B (1959) The motivation to work New York, Wiley.

Innes, J and Clarke, A (1985) Job involvement as a moderator variable in the life events stress-illness relationship Journal of occupational behaviour 6:299-303.

Jackson, S (1984) Organisational practices for preventing burnout. In A Sethi and R Schuler (eds.) Handbook of organisational stress coping strategies Cambridge, MA, Ballinger Publishing Company.

Jackson, S, Zedeck, S and Summers, E (1985) Family life disruptions: effects of jobinduced structural and emotional interference Academy of management journal 28:574586.

Jackson, S, Schwab, R and Schuler, R (1986) Toward an understanding of the burnout phenomenon Journal of applied psychology 71:630-640.

Janis, I (1972) Victims of groupthink Boston, Houghton Mifflin.

Kanter, R (1977) Work and the family in the United States: a critical review and agenda for research and policy New York, Russell Sage.

Kanungo, R (1979) The concepts of alienation and involvement revisited Pychological bulletin 86:119-136.

Kanungo, R and Misra, S (1988) The bases of involvement in work and family contexts International journal of psychology 23:267-282.

Lawler, E (1988) Choosing an involvement strategy Academy of management executive 2:197-204

Little, R (1985) An examination of the relationship of structural and attitudinal variable to occupational and organisational commitment Unpublished doctoral dissertation, Virginia Polytechnic and State University.

Locke, E, Schweiger, D and Latham, G (1986) Participation in decision making: When should it be used? Organizational dynamics 14(3):65-79.

Margerison, C and Kakabadse, A (1984) How American chief executives succeed: implications for developing high-potential employees New York, American Management Association.
Milgram, S (1974) Obedience to authority New York, Harper \& Row.

Morrow, P (1983) Concept redundancy in organisational research: the case of work commitment Academy of management review 8:486-500.

Mowday, R, Porter, L and Steers, R (1982) Employee-organisation linkages:the psychology of commitment, absenteeism and turnover New York, Academic Press.

Mowday, R, Steers, R and Porter, L (1979) The measurement of organisational commitment Journal of vocational behavior 14:224-247.

O'Driscoll, M and Schubert, T (1988) Organisational climate and burnout in a New Zealand social service agency Work \& stress 2:199-204.

Ogilvie, J (1986) The role of human resource management practices in predicting organisational commitment Group \& organisational studies 11:335-359.

O'Reilly, C and Chatman, J (1986) Organisational commitment and psychological attachment: the effects of compliance, identification and internalization on prosocial behavior Journal of applied psychology 71:492-499.

Rabinowitz, S and Hall, D (1977) Organisational research on job involvement Psychological bulletin 84:265-288.

Randall, D (1987) Commitment and the organisation: the organisation man revisited Academy of management review 12:460-471.

Randall, D (1988) Multiple roles and organisational commitment Journal of organisational behavior 9:9-317.

Salancik, G (1977) Commitment and the control of organisational behavior and belief. In B Staw and G Salancik (eds.) New directions in organisational behavior Malabar, Florida, Robert E. Krieger Publishing Company, Inc.

Sashkin, M (1986) Participative management remains an ethical imperative Organizational dynamics 14(4):62-75.

Turner, A and Lawrence, P (1965) Industrial jobs and the worker: investigation of response to task attributes Boston, MA, Harvard University Press.

Ward, C and Eisler, R (1987) Type A behavior, achievement, striving and a dysfunctional self-evaluation system Journal of personality and social psychology 53:318-326. 


\section{THE JOURNAL OF INDUSTRIAL RELATIONS}

The Journal of the Industrial Relations Society of Australia

Editor: Professor John Niland, The University of New South Wales

March 1989 - Volume 31 Number 1

Articles

Shoring up the System: The ALP and Arbitration in the 1940s Tom Sheridan

Political Economy and Management Strategy in the Metal and Engineering Industry

Tom Bramble

The Use of Seniority in Labour Selection and Job Allocation Duncan Macdonald

The Vehicle Industry Occupational Health and Safety Award, 1986 Michael McDonald

The 'New' Powers of the Australian Industrial Relations

Commission

Jeff Shaw

Annual review

Industrial Relations Legislation in 1988

J.E. Stackpool

Major Tribunal Decisions in 1988

Graham Harbord

Wages Policy and Wage Determination in 1988

Keith Norris

Australian Trade Unionism in 1988

Keri Spooner

Book reviews

Published quarterly. Subscriptions: Australia $\$ 40$, overseas $\$ 50$ (surface mail). Single issues: $\$ 12$ (including postage), overseas $\$ 14$ (surface mail). Prices quoted are in Australian dollars and remittances should be in Australian dollars. Order from the Business Manager, The Journal of Industrial Relations, GPO Box 4479, Sydney, NSW 2001, Australia. 